\title{
DISEMINASI ALAT-ALAT PROSES PRODUKSI PADA USAHA PRODUKSI SLONDOK PUYUR DI SUMURARUM KECAMATAN GRABAG KABUPATEN MAGELANG
}

\author{
Darmanto $^{1^{*} \text {, Moch. Subchan Mauludin }}{ }^{2}$, Laeli Kurniasari ${ }^{3}$, Indah Hartati ${ }^{4}$ \\ ${ }^{1}$ Jurusan Teknik Mesin, Fakultas Teknik Universitas Wahid Hasyim Semarang \\ Jl. Menoreh Tengah X/22, Sampangan, Semarang 50236 \\ ${ }^{2}$ Jurusan Teknik Informatika, Fakultas Teknik Universitas Wahid Hasyim Semarang \\ Jl. Menoreh Tengah X/22, Sampangan, Semarang 50236 \\ ${ }^{3}$ Jurusan Teknik Kimia, Fakultas Teknik Universitas Wahid Hasyim Semarang \\ Jl. Menoreh Tengah X/22, Sampangan, Semarang 50236 \\ ${ }^{4}$ Jurusan Teknik Kimia, Fakultas Teknik Universitas Wahid Hasyim Semarang \\ Jl. Menoreh Tengah X/22, Sampangan, Semarang 50236 \\ *Email: darmanto@unwahas.ac.id
}

\begin{abstract}
Abstrak
Salah satu produk olahan singkong unggulan dari Kabupaten Magelang adalah produk slondok dan puyur. Permasalahan yang dihadapi oleh mitra pelaku usaha produksi slondok puyur yang terkait aspek teknologi adalah persoalan yang timbul akibat penerapan: proses pengeringan menggunakan sinar matahari, proses penggilingan menggunakan alat konvensional dengan pemutar dari roda sepeda yang tidak higienis dan berpotensi menimbulkan kecelakaan kerja, serta proses perajangan manual dengan alat terbuat dari kayu dengan plat pisau yang terbuka yang tidak higienis dan berpotensi menimbulkan kecelakaan kerja. Guna mengatasi permasalah mitra pelaku usaha produksi slondok puyur, telah dilakukan diseminasi teknologi alatalat proses produksi berupa introduksi alat pengering resirkulasi, alat perajang dengan plat pisau perajang tertutup, dan alat penggiling adonan dengan gear reducer. Hasil uji penerapan alat pengering resirkulasi menunjukkan jika waktu proses pengeringan membutuhkan waktu yang lebih singkat jika dibandingkan dengan pengeringan sinar matahari. Penerapan alat alat perajang dengan plat pisau perajang tertutup, dan alat penggiling adonan dengan gear reducer mampu meningkatkan higienitas produksi, menurunkan potensi keselamatan kerja dan menurunkan biaya produksi.
\end{abstract}

Kata kunci: diseminasi, alat proses produksi, slondok puyur.

\section{PENDAHULUAN}

Slondok dan puyur merupakan salah satu produk olahan singkong yang merupakan salah satu produk unggulan Kabupaten Magelang dengan sentra industri slondok dan puyur berada di desa Sumurarum, kecamatan Grabag, Kabupaten Magelang. Slondok merupakan makanan ringan tradisional berbahan dasar singkong yang memiliki tekstur renyah seperti keripik dan rasa khas. Bentuk slondok pipih persegi panjang dengan ketebalan sekitar $2 \mathrm{~mm}$, lebar $1 \mathrm{~cm}$ dan panjang sekitar $5 \mathrm{~cm}$. Sementara bentuk puyur adalah bulat pipih dengan ketebalan sekitar $2 \mathrm{~mm}$ dan berdiameter sekitar 3-4 cm.

Proses pembuatan slondok dan puyur terdiri atas tahap persiapan bahan baku dan proses pengolahan adonan baku. Proses persiapan bahan baku dimulai dari pengupasan kulit singkong, pencucian, pemarutan, pengepresan, dan pengukusan. Adapun proses pengolahan adonan baku untuk produksi puyur adalah parutan singkong yang sudah dikukus lantas digiling dan dicetak hingga diperoleh adonan berbentuk silinder dengan diameter $5 \mathrm{~cm}$ dan panjang 50-60 cm. Setelah adonan tercetak, adonan tersebut diangin-anginkan selama kurang lebih 2 hari untuk menurunkan kadar airnya untuk selanjutnya adonan puyur dirajang dan dikeringkan. Sementara itu proses pengolahan adonan baku untuk produksi slondok adalah parutan singkong yang sudah dikukus 
lantas dan berbentuk kerucut (tumpeng) didiamkan selama 3 hari dan setelah itu bagian tepi tumpeng dikupas untuk memudahkan proses penggilingan. Setelah dikupas bagian tepinya, selanjutnya tumpeng dirajang secara manual menggunakan pisau untuk selanjutnya digiling. Setelah keluar dari mesin giling slondok, adonan slondok basah berbentuk tipis panjang dipotong kurang lebih sepanjang $50 \mathrm{~cm}$. Slondok basah tersebut ditempatkan pada rak-rak dengan kondisi masih saling lengket selanjutnya akan didiamkan selama kurang lebih 5 jam supaya teksturnya menjadi agak keras/kaku dan berkurang kadar airnya serta tidak lengket sehingga tidak mudah putus/hancur saat dipisahkan satu sama lain. Slondok basah selanjutnya dikeringkan menggunakan sinar matahari.

Dalam proses produksi slondok dan puyur, pelaku usaha produksi slondok di desa Sumurarum, kecamatan Grabag, Kabupaten Magelang menghadapi beberapa permasalahan yang terkait aspek teknologi, yakni: (i) proses pengeringan menggunakan sinar matahari efektif pada musim kemarau, namun demikian proses pengeringan tidak higienis, (ii) proses penggilingan menggunakan alat konvensional dengan pemutar dari roda sepeda yang tidak higienis, dan berpotensi menimbulkan kecelakaan kerja, dan (iii) proses perajangan masih dilakukan secara manual dengan alat terbuat dari kayu dengan plat pisau yang terbuka sehingga proses tesebut tidak higienis dan berpotensi menimbulkan kecelakaan kerja. Menimbang uraian permasalahan tersebut, maka melalui kegiatan diseminasi teknologi, telah dilakukan upaya perbaikan proses produksi melalui introduksi dan penerapan alat pengering resirkulasi, alat perajang dengan plat pisau perajang tertutup, dan alat penggiling adonan dengan gear reducer.

\section{METODE PELAKSANAAN}

Program diseminasi teknologi alat alat proses produksi pada usaha produksi slondok puyur dilakukan melalui tahapan sebagaimana disajikan pada Gambar 1 dengan detail sasaran dan indikator capaian disajikan pada Tabel 1.

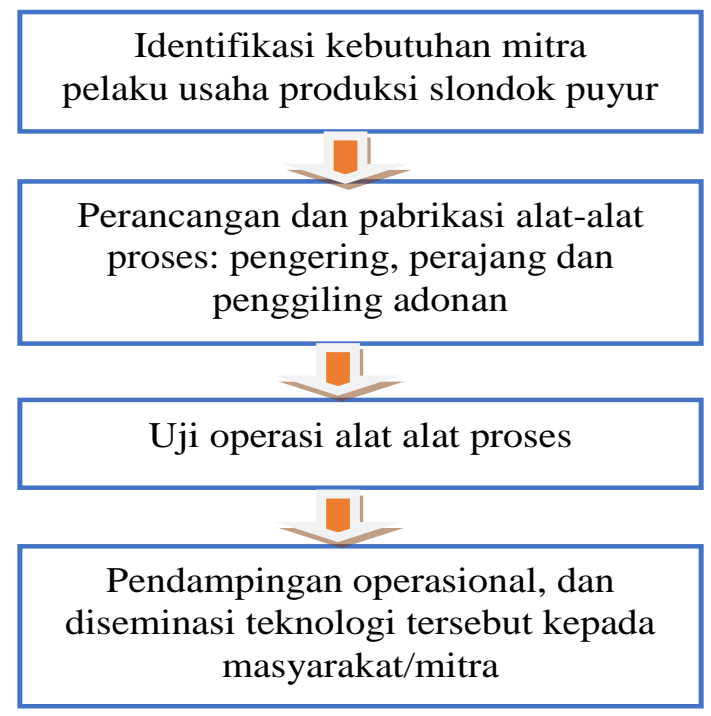

\section{Gambar 1. Tahapan proses diseminasi teknologi alat alat proses produksi pada usaha produksi slondok puyur}

Identifikasi kebutuhan masyarakat dilakukan melalui survey ke lokasi mitra serta wawancara dan diskusi dengan mitra untuk menggali skala prioritas permasalahan. Perancangan dan pabrikasi alat alat pengering resirkulasi, alat perajang dengan plat pisau perajang tertutup, dan alat penggiling adonan dengan gear reducer dilakukan di workshop T Mesin Unwahas selama 4 bulan. Uji coba alat dilakukan di Workshop dan di lokasi mitra. Uji coba di workshop dimaksudkan untuk memastikan bahwa alat berfungsi baik. Setelah uji fungsional menunjukkan hasil positif, alat dibawa ke lokasi mitra dan diuji coba menggunakan bahan yang disediakan mitra. Apabila uji 
fungsi di lokasi mitra menunjukkan hasil yang baik, maka alat diserahterimakan dan digunakan pada proses produksi. Pendampingan operasional dilakukan dengan diawali pelatihan cara penggunaan dan perawatan. Tim pelaksana menyusun SOP penggunaan, keselamatan kerja dan SOP perawatan. Dokumen dokumen tersebut diperkenalkan dan dijelaskan bersamaan dengan proses pelatihan penggunaan alat serta pada proses pendampingan. Pada proses pendampingan dan diseminasi teknologi, mitra berperan menjadi sasaran kegiatan, menyediakan lokasi pendampingan dan pelatihan serta menyediakan bahan baku yang digunakan pada proses pendampingan.

Tabel 1. Rincian sasaran, luaran, dan indicator capaian kegiatan

\begin{tabular}{|c|c|c|}
\hline No & Sasaran & Indikator Capaian \\
\hline 1. & $\begin{array}{l}\text { Penerapan alat pengering } \\
\text { ergonomis resirkulasi } \\
\text { dilengkapi pelatihan } \\
\text { penggunaan, } \\
\text { pendampingan, dan } \\
\text { perawatan alat }\end{array}$ & $\begin{array}{l}\text { Alat pengering ergonomis resirkulasi dengan spesifikasi: } \\
\text { - dimensi }(\mathrm{p} \times 1 \times \mathrm{t}): 200 \times 180 \times 90 \mathrm{~cm} \text {, blower } 2 \text { buah ( } 1 \\
\text { phase } 50 \mathrm{~W} 220 \mathrm{~V} \text { ), pemanas burner gas (double), } \\
\text { temperatur kerja } 60^{\circ} \mathrm{C} \text {, sirkulasi dari samping, kapasitas } 50 \\
\mathrm{~kg} \text {, material dinding dalam stainless steel } \\
\text { - Terlaksananya proses pelatihan, pendampingan dan } \\
\text { perawatan }\end{array}$ \\
\hline 2. & $\begin{array}{l}\text { Penerapan } \\
\text { penggiling dengan gear } \\
\text { reducer yang dilengkapi } \\
\text { dengan pelatihan } \\
\text { penggunaan rat, } \\
\text { pendampingan, dan } \\
\text { perawatan alat }\end{array}$ & $\begin{array}{l}\text { - alat penggiling dengan gear reducer dengan spesifikasi: } \\
\text { dimensi } 1 \text { x } 0,5 \times 0,5(\mathrm{~m}) \text {, motor listrik ( } 1 \text { phase, } 1 \mathrm{Hp}, 1400 \\
\text { rpm), transmisi kopling pulley v belt, gear ratio 20, kapasitas } \\
75 \mathrm{~kg} / \text { jam dan meja kerja plat stainles steel } \\
\text { - Terlaksananya proses pelatihan, pendampingan dan } \\
\text { perawatan }\end{array}$ \\
\hline 3. & $\begin{array}{l}\text { Penerapan alat } \\
\begin{array}{l}\text { perajang } \\
\text { dengan plat } \\
\text { perajang } \\
\text { dilengkapi } \\
\text { penggunaan, } \\
\text { pendampingan, } \\
\text { perawatan alat }\end{array}\end{array}$ & $\begin{array}{l}\text { - alat perajang dengan plat perajang tertutup dengan } \\
\text { spesifikasi: dimensi } 0,5 \times 0,5 \times 0,5(\mathrm{~m}) \text {, motor listrik ( } 1 \\
\text { phase, } 1 \mathrm{Hp}, 1400 \mathrm{rpm}) \text {, transmisi pulley v belt, pemotong } \\
\text { rotary } 4 \text { mata pisau, kapasitas } 75 \mathrm{~kg} / \mathrm{jam} \text { dan pemakanan } 1 \\
\text { lubang } \\
\text { - Terlaksananya proses pelatihan, pendampingan dan } \\
\text { perawatan }\end{array}$ \\
\hline
\end{tabular}


HASIL DAN PEMBAHASAN

Perancangan dan pabrikasi alat pengering resirlukasi ergonomis, perajang dengan plat perajang tertutup, penggiling dengan gear reducer

Alat pengering resirkulasi ergonomis, perajang dengan plat perajang tertutup dan penggiling dengan gear reducer merupakan alat-alat yang digunakan pada produksi slondok dan puyur. Perancangan alat pengering resirkulasi ergonomis, perajang dengan plat perajang tertutup dan penggiling dengan gear reducer dilakukan dengan alur sebagaimana tersaji pada Gambar 2.

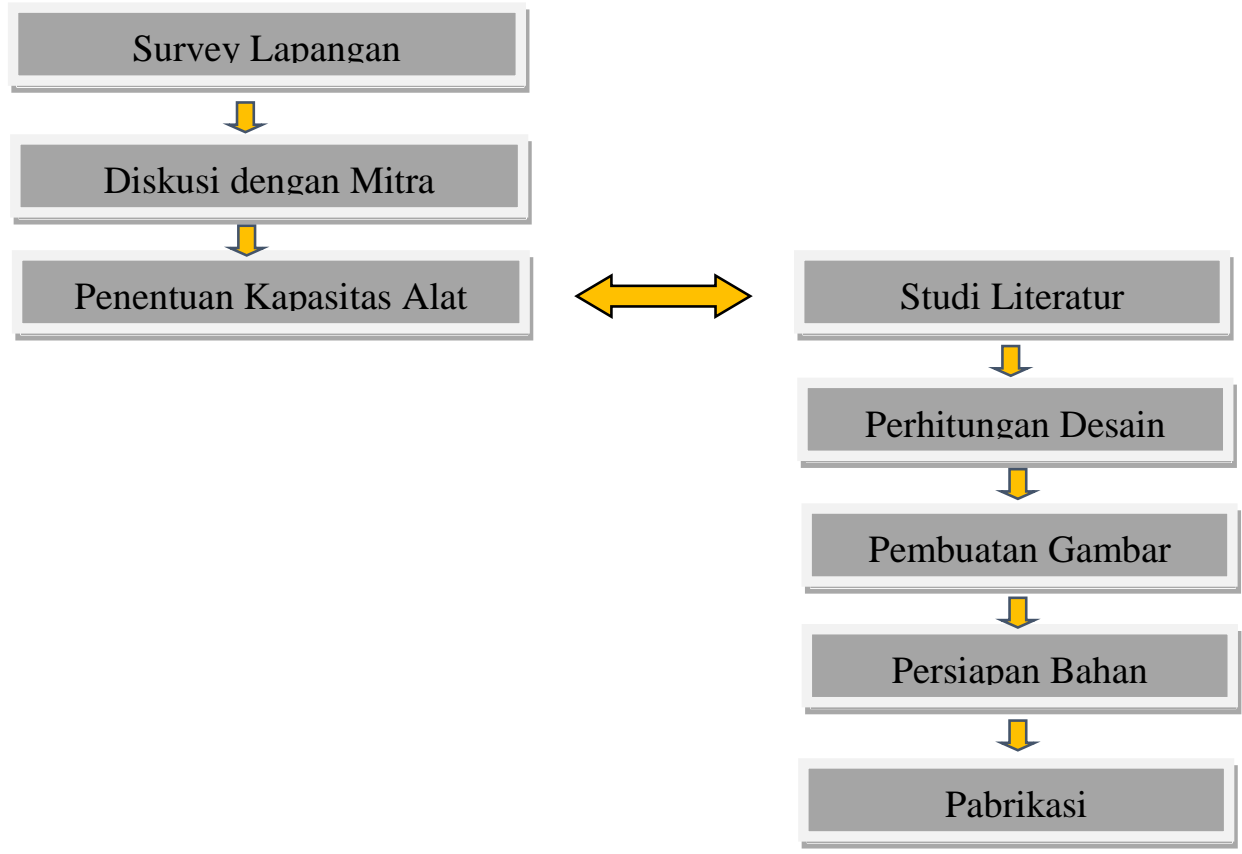

\section{Gambar 2. Alur Perancangan Alat}

Survey lapangan telah dilakukan melalui kunjungan ke lokasi mitra pelaku usaha produksi slondok puyur (Gambar 3). Diskusi telah dilakukan terkait penentuan kapasitas pengering resirkulasi ergonomis, perajang dengan plat perajang tertutup dan penggiling dengan gear reducer. Diksusi juga dilakukan untuk menentukan space untuk perencanaan tata letak alat proses yang akan diintroduksi. Berdasarkan hasil diskusi dengan mitra telah disepakati bahwa kapasitas alat yang akan didesain dan dipabrikasi adalah alat pengering dengan kapasitas $50 \mathrm{~kg} / \mathrm{batch}$, alat perajang dengan kapasitas $75 \mathrm{~kg} / \mathrm{jam}$ dan alat penggiling dengan kapasitas $75 \mathrm{~kg} / \mathrm{jam}$.
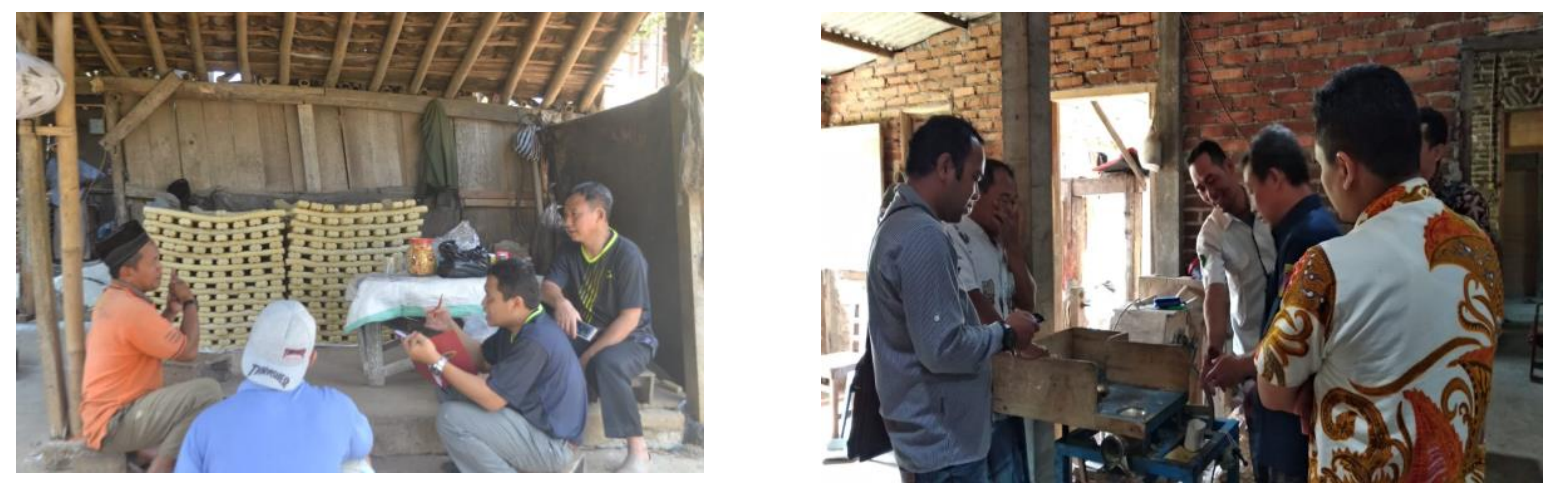

Gambar 3. Survei lapangan terkait diskusi penentuan kapasitas alat dan tata letak alat proses 
Studi literatur merupakan tahap lanjutan dari penentuan kapasitas. Studi literatur dilakukan untuk mendapatkan acuan mengenai komponen-komponen alat-alat pengering resirkulasi ergonomis, perajang dengan plat perajang tertutup dan penggiling dengan gear reducer, serta basis perhitungan perancangan alat proses. Selanjutnya alat-alat pengering resirkulasi ergonomis, perajang dengan plat perajang tertutup dan penggiling dengan gear reducer dipabrikasi di Workshop Teknik Mesin Unwahas.

\section{Uji Operasi Alat-alat proses}

Uji alat proses dilakukan dilakukan di Workshop dan di lokasi mitra (Gambar 4). Uji coba di workshop dimaksudkan untuk memastikan bahwa alat berfungsi baik. Uji fungsi alat pengering resirkulasi ergonomis, perajang dengan plat perajang tertutup dan penggiling dengan gear reducer menunjukkan jika alat berfungsi dengan baik.

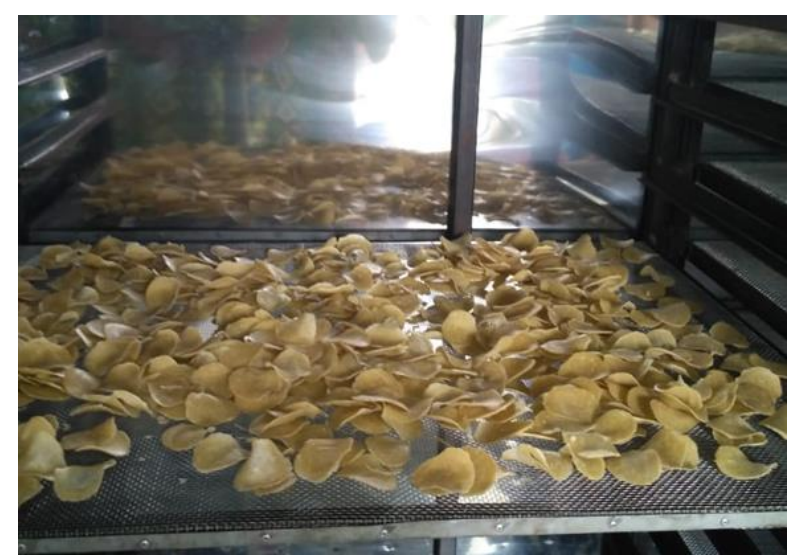

Gambar 4. Uji alat proses pengering resirkulasi

Uji fungsi alat pengering juga dilakukan dengan menganalisa kinetika pengeringan produk slondok puyur. Hasil analisa uji kinetika pengeringan menunjukkan jika alat pengering resirkulasi mampu mengeringkan produk dengan waktu yang lebih singkat jika dibandingkan dengan proses pengeringan dengan sinar matahari. Proses pengeringan dengan sinar matahari selama 60 menit mampu menghasilkan produk dengan kadar air sebesar 4\%. Sementara alat pengering resirkulasi mampu menghasilkan produk puyur dengan kadar air yang sama melalui proses pengeringan selama 45 menit. Hal tersebut didukung dengan hasil analisa kinetika pengeringan menurut model kinetika Lewis dan Henderson-Pabis (Hartati dkk.,2018). Hasil analisa data proses uji fungsi alat pengering menunjukkan jika nilai kontanta kecepatan pengeringan menggunakan alat pengering resirkulasi lebih besar jika dibandingkan dengan konstanta pengeringan puyur dengan sinar matahari sebagaimana disajikan pada Tabel 2.

Tabel 2. Nilai konstanta kecepatan pengeringan sinar matahari dan pengering resirkulasi pada proses pengeringan produk puyur

\begin{tabular}{lccc}
\hline Model kinetika & $\begin{array}{c}\text { Pengeringan } \\
\text { matahari }\end{array}$ & \multicolumn{2}{c}{ Pengering resirkulasi } \\
Suhu $60^{\circ} \mathrm{C}$ & Suhu $50^{\circ} \mathrm{C}$ \\
\hline Lewis & 0,0301 & 0,0547 & 0,0349 \\
Henderson-Pabis & 0,0306 & 0,0553 & 0,0343 \\
\hline
\end{tabular}

Menimbang bahwa hasil uji fungsional menunjukkan hasil positif, maka alat dibawa ke lokasi mitra dan diuji coba menggunakan bahan yang disediakan mitra serta diserahterimakan dan digunakan pada proses produksi (Gambar 5). 


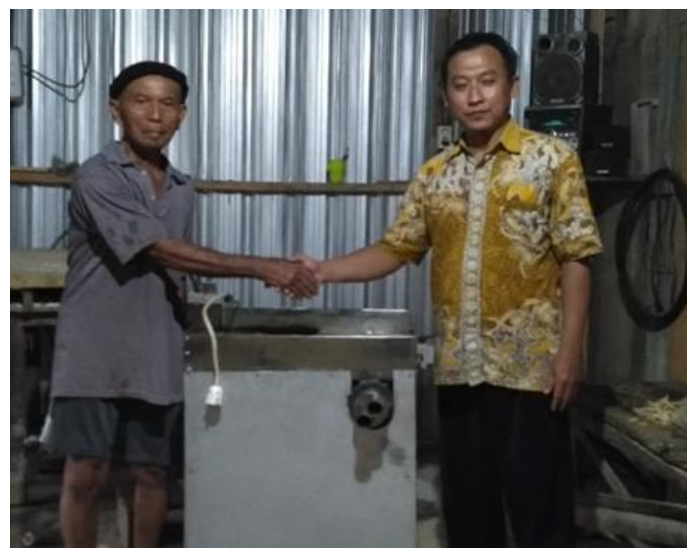

Gambar 5. Penyerahan alat-alat proses produksi pada pelaku usaha produksi slondok puyur

Pendampingan operasional dan diseminasi alat proses produksi pada pelaku usaha produksi slondok puyur

Pendampingan operasional alat dilakukan melalui pelatihan penggunaan alat perawatan alat dan keselamatan kerja yang disertai dengan introduksi dokumen SOP penggunaan, perawatan dan keselamatan kerja. Detail perbandingan spesifikasi alat dan proses konvensional yang diterapkan dengan alat alat proses yang didiseminasikan melalui kegiatan diseminasi teknologi disajikan pada Tabel 3.

Tabel 3. Spesifikasi alat dan proses konvensional yang diterapkan dengan alat alat proses yang didiseminasikan melalui kegiatan diseminasi teknologi

Proses dan spesifikasi alat yang digunakan dalam proses produksi slondok puyur Sebelum dilakukan program diseminasi $\quad$ Sesudah dilakukan program diseminasi

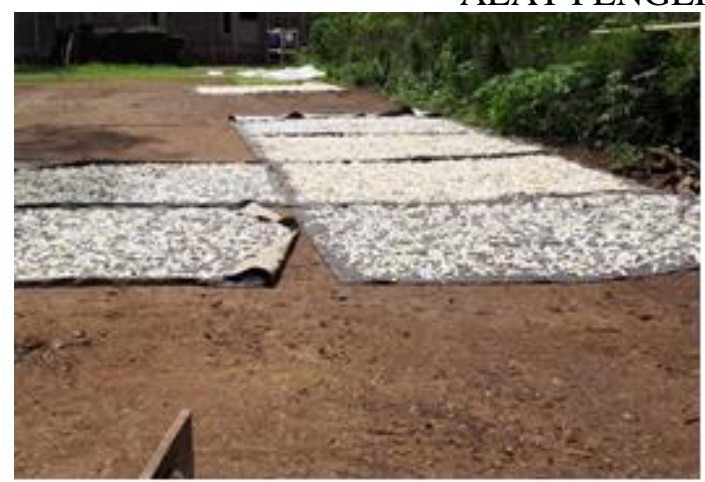

Butuh Waktu 6 jam untuk pengeringan

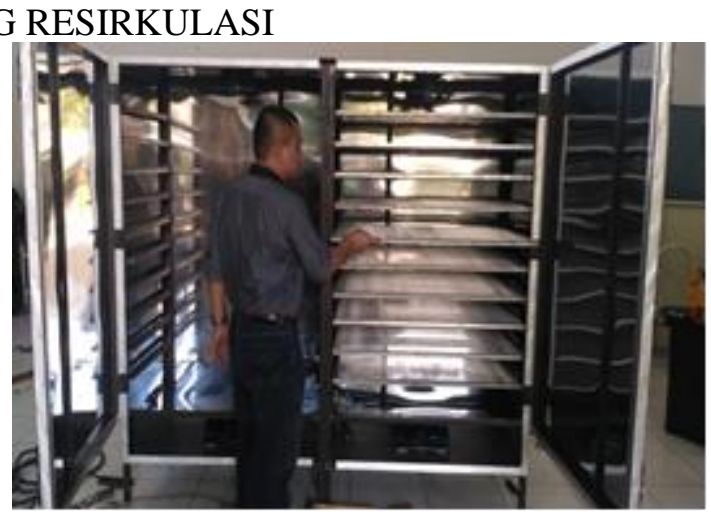

- $\quad$ Dimensi (p x l x t) : 200 x 180 x $90 \mathrm{~cm}$

- Kapasitas: $50 \mathrm{Kg}$

- Temperatur kerja $60{ }^{\circ} \mathrm{C}$, membuthkan waktu pengeringan 4 jam

- Dinding: stainlesteel berlapis isolator

- Double blower, double burner

- Bahan bakar : Elpiji 


\section{MESIN PENGGILING SLONDOK}

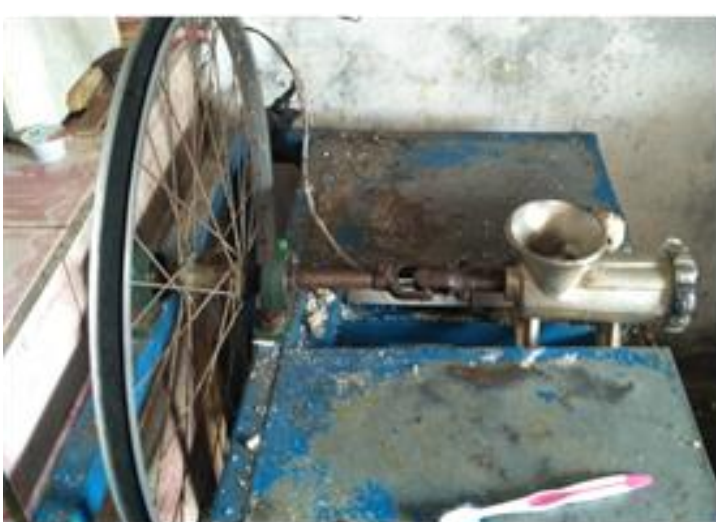

- $\quad$ Dimensi (p x 1 x t) : 70 x 60 x $90 \mathrm{~cm}$

- Kapasitas : $75 \mathrm{Kg}$

- Penggerak : Motor listrik 1,5 Hp

- Transmisi : Pully - Belt - Peleg sepeda

- Rangka : plat Baja

- Cover : tidak ada

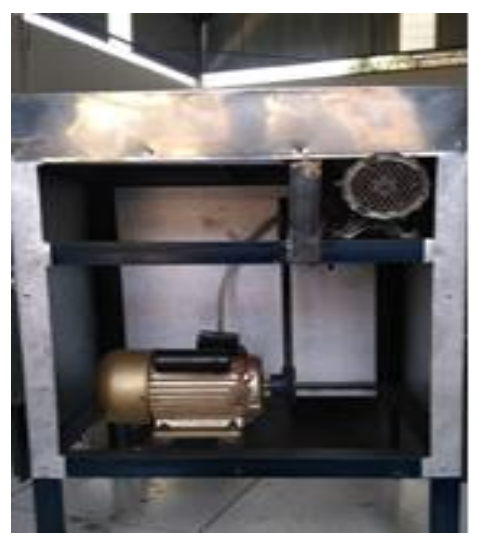

- $\quad$ Dimensi (p x 1 x t) : 60 x 60 x $90 \mathrm{~cm}$

- Kapasitas : $75 \mathrm{Kg}$

- $\quad$ Penggerak : Motor listrik 0,75 Hp

- Transmisi : Pully - Belt - Gear Reducer

- Rangka : plat Baja

- Cover : stainlesteel

\section{MESIN PERAJANG SLONDOK}

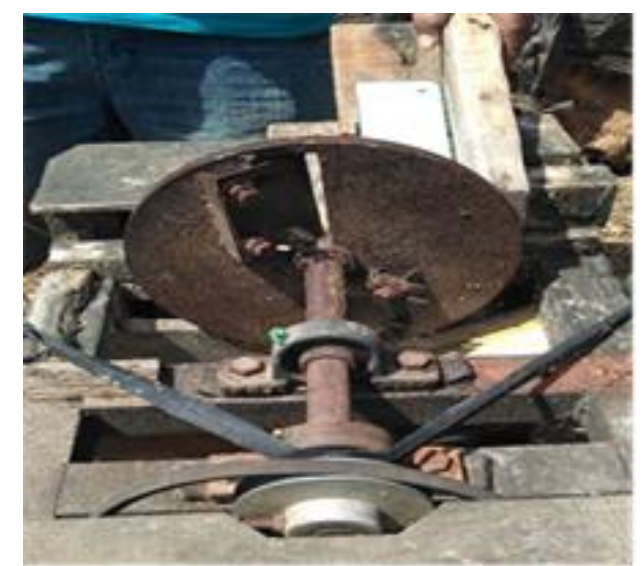

Dimensi $(\mathrm{p} \times 1 \times \mathrm{t}): 60 \times 60 \times 90 \mathrm{~cm}$

- Kapasitas : $75 \mathrm{Kg}$

- Penggerak : Motor listrik 1,5 Hp

- Transmisi : Pully - Belt

- $\quad$ Cover : tidak ada

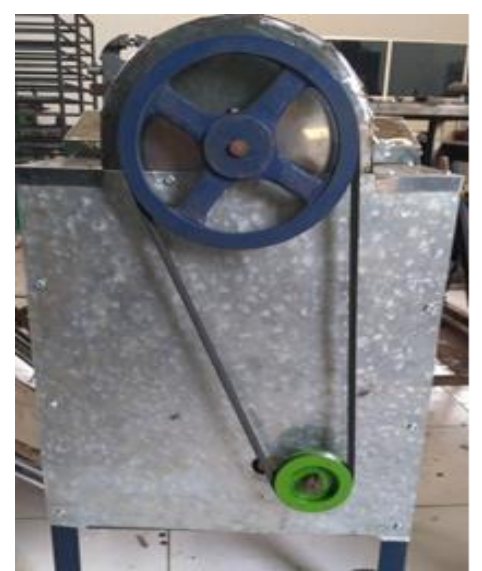

Dimensi (p x 1 x t) : $60 \times 60 \times 90 \mathrm{~cm}$

- Kapasitas : $75 \mathrm{Kg}$

- $\quad$ Penggerak : Motor listrik $1 \mathrm{Hp}$

- Transmisi : Pully - Belt

- Rangka : plat Baja

- Cover : stainlesteel

Lebih lanjut, diseminasi alat-alat proses berupa alat pengering resirkulasi ergonomis, perajang dengan plat perajang tertutup dan penggiling dengan gear reducer telah mampu memberikan fungsi dan manfaat pada industry pembuatan slondok puyur adalah sebagai berikut:

a. Fungsi dan manfaat alat pengering resirkulasi

Alat pengering ergonomis resirkulasi dengan spesifikasi: dimensi $(\mathrm{p} \times 1 \times \mathrm{t}): 200 \times 180 \times 90$ $\mathrm{cm}$, blower 2 buah ( 1 phase $50 \mathrm{~W} 220 \mathrm{~V}$ ), pemanas burner gas, temperatur kerja $60^{\circ} \mathrm{C}$, sirkulasi dari samping, kapasitas $50 \mathrm{~kg}$, material dinding dalam stainless steel mampu mengeringkan produk slondok puyur dengan proses pengeringan yang lebih cepat dan waktu yang lebih singkat bila dibandingkan dengan proses pengeringan dengan sinar matahari, mampu meningkatkan kualitas produk, mampu mengatasi permasalahan pengeringan di 
musim penghujan dan mampu menurunkan biaya produksi khusunya di musim penghujan karena mampu meminimalkan terjadinya produk gagal.

b. Fungsi dan manfaat alat perajang adonan slondok puyur dengan plat perajang tertutup Alat perajang dengan plat perajang tertutup dengan spesifikasi: dimensi $0,5 \times 0,5 \times 0,5(\mathrm{~m})$, motor listrik ( 1 phase, $3 / 4 \mathrm{Hp}, 1400 \mathrm{rpm}$ ), transmisi pulley v belt, pemotong rotary 4 mata pisau, kapasitas $75 \mathrm{~kg} / \mathrm{jam}$ dan pemakanan 1 lubang berfungsi menjadi alat perajang yang mampu meningkatkan kapasitas produksi, mampu meningkatkan keselamatan kerja pekerja produksi slondok puyur dan mampu meningkatkan kehigienitasan proses produksi slondok puyur.

c. Fungsi dan manfaat alat penggiling adonan slondok puyur dengan gear reducer Alat penggiling dengan gear reducer dengan spesifikasi: dimensi $1 \times 0,5 \times 0,5(\mathrm{~m})$, motor listrik ( 1 phase, $1 \mathrm{Hp}, 1400 \mathrm{rpm}$ ), transmisi kopling pulley v belt, gear ratio 20, kapasitas 75 $\mathrm{kg} / \mathrm{jam}$ dan meja kerja plat stainles steel mampu berfungsi menjadi alat penggiling yang mampu meningkatkan kapasitas produksi, mampu meningkatkan keselamatan kerja pekerja industry slondok puyur mampu meningkatkan kehigienitasan proses produksi slondok puyur

\section{KESIMPULAN}

Introduksi alat-alat proses produksi pada usaha produksi slondok puyur mampu meningkatkan kapasitas produksi, meminimalkan biaya akibat terjadinya pengolahan ulang produk yang kurang kering sempurna. Penerapan alat produksi yang dibuat dengan mempertimbangkan unsur keselamatan kerja mampu memberikan rasa aman bagi para pekerja. Penerapan alat produksi yang dibuat dengan mempertimbangkan unsur kebersihan sarana kerja juga mampu meningkatkan kepercayaan dan memotivasi UKM untuk mengajukan perijinan-perijinan usaha dan produk.

\section{DAFTAR PUSTAKA}

Hartati I., Kusumaningrum M., Kurniasari L. 2018. Pengeringan Busa Terhadap Ampas Seduhan Teh Menurut Model Kinetika Lewis, Page Dan Henderson-Pabis. Jurnal Inovasi Teknik Kimia Vol 3 No 